\title{
ARE FOSSIL FUELS THE MAIN CAUSE OF TODAY'S GLOBAL WARMING?
}

\author{
UDC 553.981.3:552.57; 644.19:504.75
}

\author{
Dejan Brkić \\ Ministry of Science and Technological Development of Serbia, Belgrade \\ dejanrgf@tesla.rcub.bg.ac.rs
}

\begin{abstract}
Gas will increasingly be seen as the fossil fuel of choice, especially when considering environmental impacts. Natural gas is the chance for Serbia for sustainable development and with its intensive consumption in the XXI century to conciliate the 4Es (Energy, Economy, Efficiency and Environment). In this paper we will compare the impact of different fossil fuels used for domestic heating with a special emphasis on natural gas. Some other causes of climate changes will be also discussed such as the Milankovic astronomical cycles. These factors will be compared with climate changes caused by the consumption of fossil fuels.
\end{abstract}

Key Words: Natural gas, Fossil fuels, Domestic heating, Ecology, Milanković cycles

\section{INTRODUCTION}

Many factors affect climate change at orbital time scales, including external forcing (insolation) and the results are changes in ice volume and greenhouse gases that produce interactions within the climate system.

Natural gas in Serbia is expected to be the primary substitute for electricity based heating either through district heating in densely populated areas or individual boilers $[5,6]$. The extension of the gas networks is extremely important for Serbia's overall energy and environment strategy $[7,8]$. An increase in the share of natural gas energy is the strategic option and its consumption should increase at the highest rate as the result of substitution of other fuels and increased demand. These issues are especially in focus these days since the oil and gas agreement with Russia was signed $[7,8]$. In a discussion on the environmental impact of fossil fuels oriented heating, one has to be very careful since in the global earth climate system other factors of influence exist, such as astronomical ones [24]. The Milanković cycles, named after the Serbian scientist Milutin Milanković have a great impact on earth's climate [24]. Fossil fuels are the dominant polluter today, but are 
they main cause of obvious climate changes today? Today in the post-Kyoto world, reduction of $\mathrm{CO}_{2}$ is very important, but the main question is if this increased value of greenhouse gases is the main cause of climate changes, or to the contrary, is this increased level of greenhouse gas only a consequence of climate changes caused by other sources. The fact is that the current level of atmospheric $\mathrm{CO}_{2}$ is far below the maximal values which had been occurring in some of the old geological eras [33] (Figure 1). Urban areas have experienced a local increase of temperature usually noted as the 'urban heat island' [1]. This local temperature anomaly is possible caused by the increased presence of urban gasses.
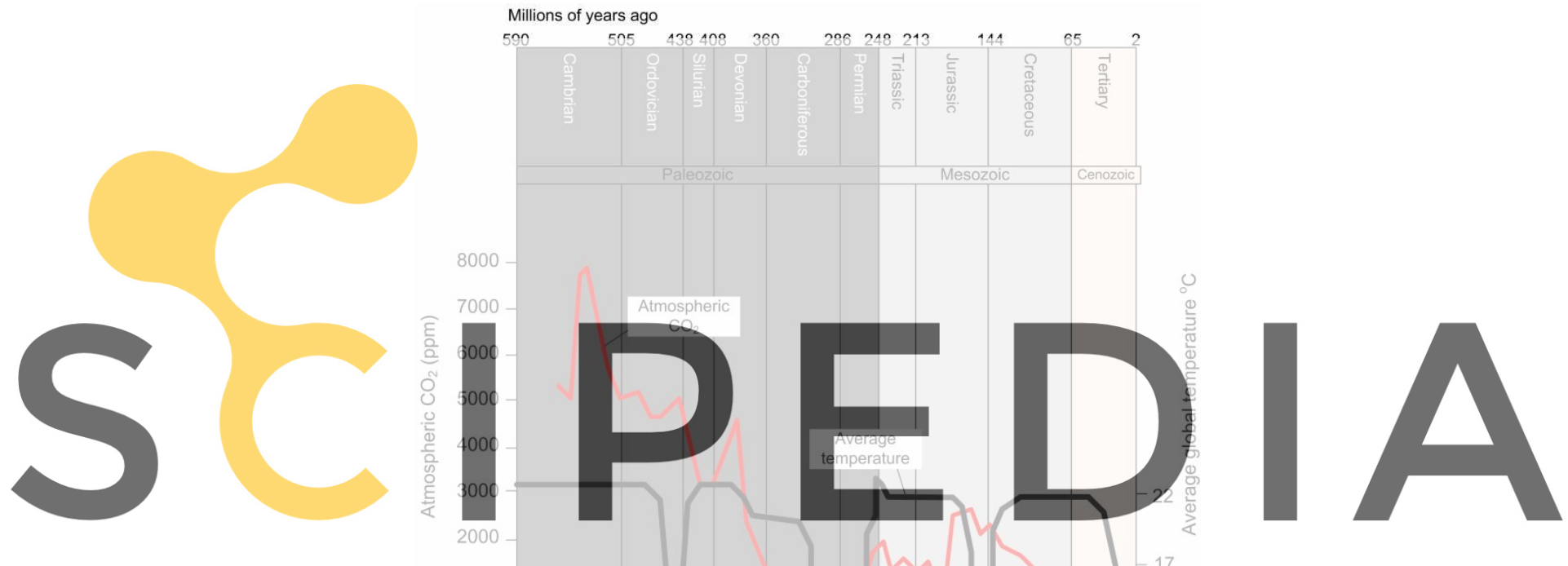

Register for free at https//Whww.scipedia.com to download the versjon without the watermark

Fig. 1. The average temperature and atmospheric $\mathrm{CO}_{2}$ for the last 600 million years (according to data from www.geokraft.com; temperature after C.T. Scootese, $\mathrm{CO}_{2}$ after R.A. Berner)

Evidence of warming is often presented as evidence of human-caused warming. The logical construction of this argument is as follows:

1. If human activity causes global warming, then the Earth will warm.

2. The Earth is warming.

3. Therefore, human activity causes global warming.

This argument is invalid because the conclusion is drawn from a common logical error known as the converse error. As a clarifying example of a converse error, consider the argument:

1. If Joe drops the glass, the glass will break.

2. The glass is broken.

3. Therefore Joe dropped the glass. 
The conclusion that Joe dropped the glass is invalid because the glass might have been dropped by anyone else, or it could have been broken by some entirely different means. By the same logic, evidence of warming is simply evidence of warming. No conclusion about the role of human activity can be drawn from it. Another invalid argument is the claim that, "If there is a consensus of scientists that global warming is human-caused, then human-caused global warming must be true". This argument is invalid for at least two reasons: first of all, the premise is not true. Consider, for example, the consensus of scientists long ago who believed the Sun and stars revolve around the Earth. Clearly, a consensus does not make it true.

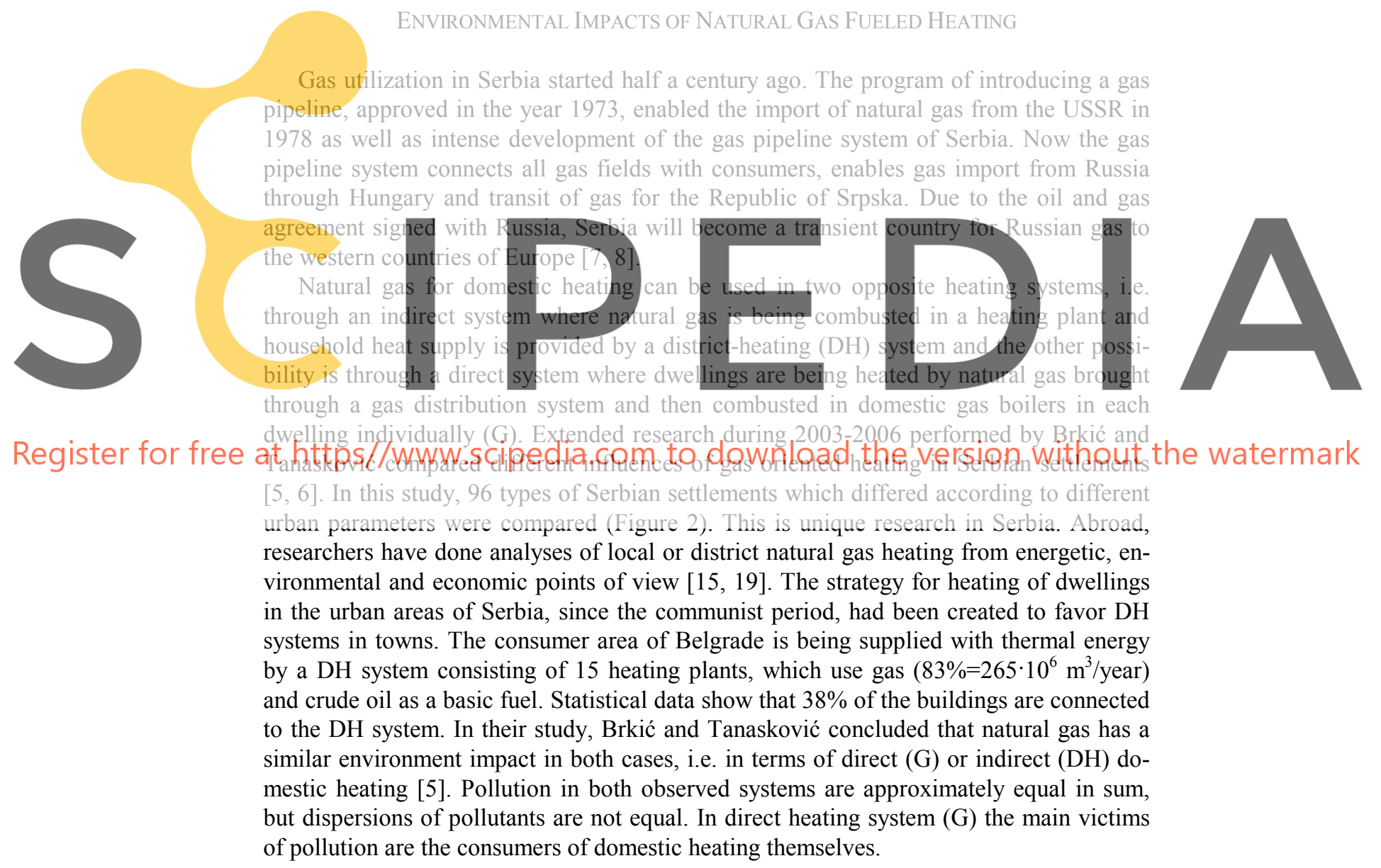




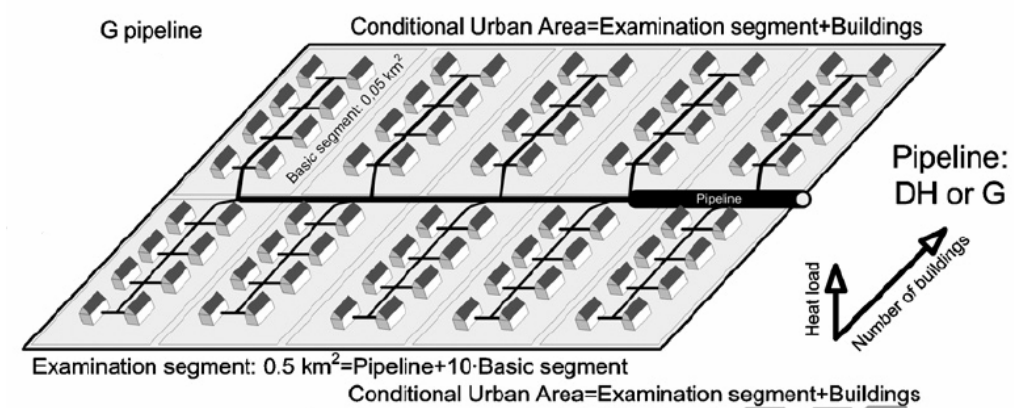

$7 T T$

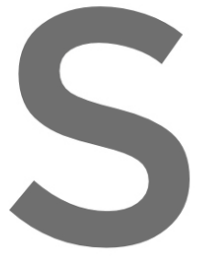

Examination segment: $0,5 \mathrm{~km}^{2}=$ Pipeline+10.Basic segment

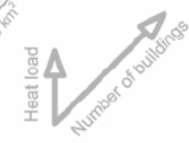

\section{(1)}

Fig.

In gas plant o
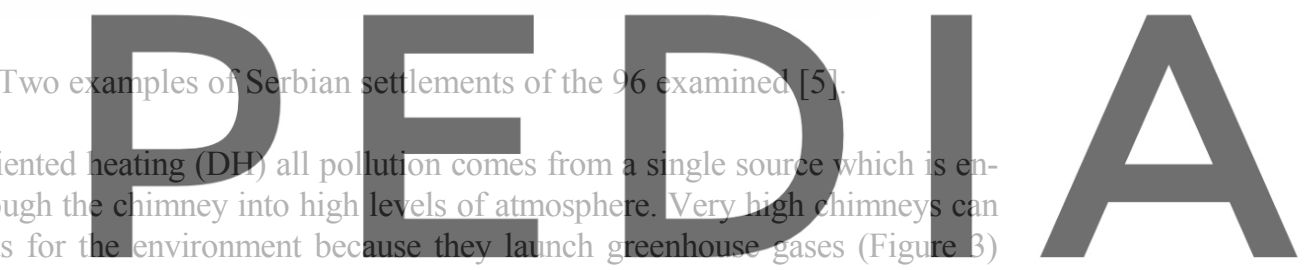

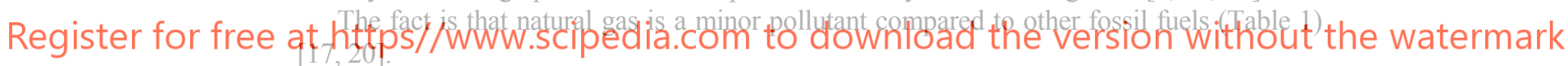

Table 1. Impact of environmental impact of different energy sources

\begin{tabular}{|l|r|r|c|}
\hline & Coal & Liquid fuel & Natural gas \\
\hline $\mathrm{SO}_{2}$ & 620 & 140 & 0.1 \\
\hline $\mathrm{NO}_{\mathrm{x}}$ & 40 & 40 & 40 \\
\hline Particles & 200 & 5 & 0.1 \\
\hline $\mathrm{HCl}$ & 20 & - & - \\
\hline $\mathrm{HF}$ & 2 & - & - \\
\hline $\mathrm{CO}$ & 6000 & 70 & 70 \\
\hline Formaldehydes & 1 & 5 & 1 \\
\hline $\mathrm{HC}$, total & 200 & 15 & 15 \\
\hline $\mathrm{CO}$ (+CO) & 99000 & 74000 & 57000 \\
\hline $\mathrm{Heavy}$ metals & & & \\
\hline $\mathrm{Cd}$ & 0.011 & - & - \\
\hline $\mathrm{Hg}$ & 0.004 & 0.0001 & 0.0001 \\
\hline $\mathrm{Pb}$ & 0.1 & - & - \\
\hline
\end{tabular}


But can we use natural gas or other fossil fuels without dire consequences? The answer is maybe but we do not really know [28]. The fact is that we have to heat our dwellings and maybe it is not a certain fact that $\mathrm{CO}_{2}$ released from the fossil fuel is the major reason for global warming $[3,20,25]$.


Fig. 4. Natural gas from deposit to final consumers [6]. 
In a distant part of the world oil infrastructure exists but natural gas pipelines do not. This is the main reason why many oil companies discard natural gas as a less interesting energy source compared with oil in the observed conditions. In that way large amounts of natural gas are burned off in the flares in oil gas fields. A consequence is that these amounts of gas are released into the atmosphere without rational preliminary usage. Annual gas flaring of natural gas in oil fields sends 84000 tonnes of carbon into the atmosphere worldwide every year [2] (Figure 5).
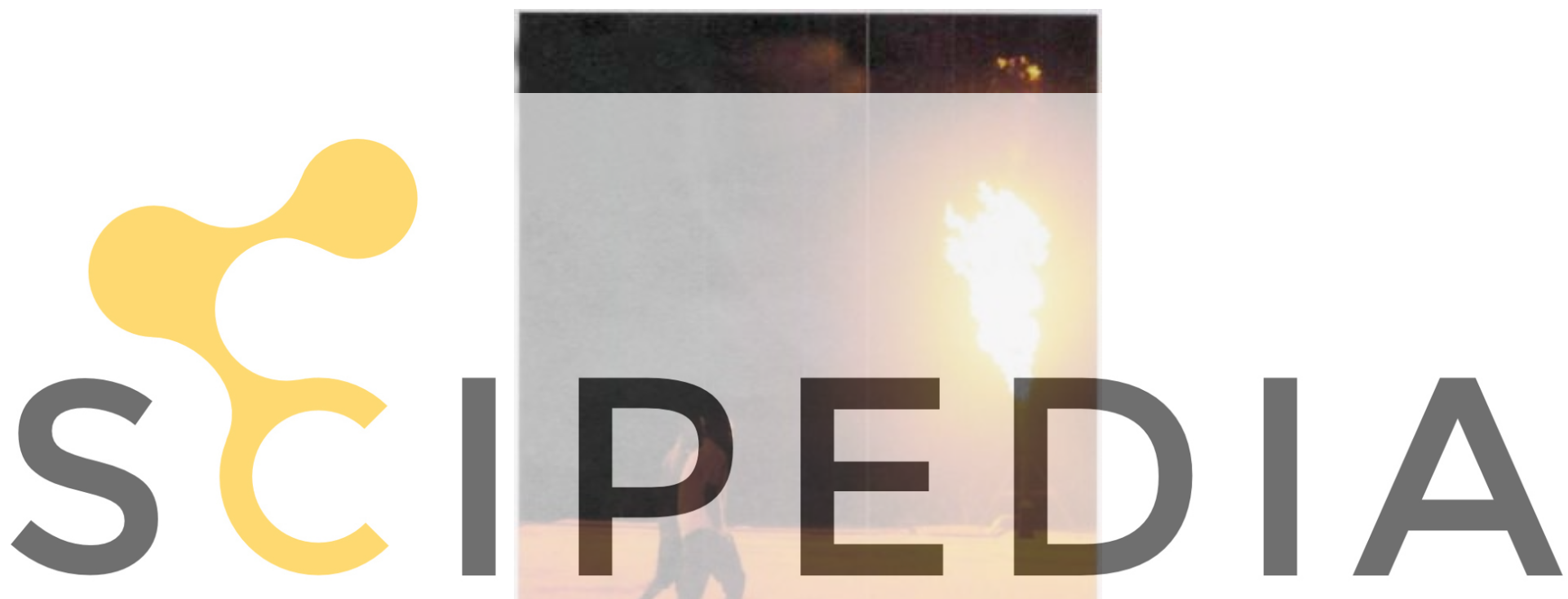

Fig. 5. What a waste: gas is burned off in oil producing areas

where there are no facilities to make use of it

Gas flaring is widely recognized as a waste of energy and an added source of atmospheric carbon emission. This flaring has fluctuated between 150 billion and 170 billion $\mathrm{m}^{3}$ a year. Note that the peak of annual Serbian indigenous production of natural gas is about 0.6 billion $\mathrm{m}^{3}$, and today is several times lower. Russia, Nigeria, Iran, Iraq, Angola and Venezuela respectively, are the biggest contributors to natural gas flaring. The UK is between the 15th and 20th biggest flarer with 0.6 billion $\mathrm{m}^{3}$ per year [2].

Here it has to be noted that the amount of $\mathrm{CO}_{2}$ is measured in ppm (parts per million) in the atmosphere, compared to the $\mathrm{CH}_{4}$ in $\mathrm{ppb}$ (parts per billion). Such small shares of these gases have a great impact on the greenhouse effect $[17,34]$. Methane $\left(\mathrm{CH}_{4}\right)$ is the main ingredient of typical natural gas. The estimated amount of $\mathrm{CO}_{2}$ in the atmosphere increased by 19 billion tonnes in 2007 . This is a rise of $0.6 \%$, lifting the concentration of $\mathrm{CO}_{2}$ to $385 \mathrm{ppm}$. 


\section{Astronomical Causes of Climate Changes}

The Milanković theory, named after Serbian civil engineer and mathematician Milutin Milanković (1879-1958), describes the collective effects of changes in the Earth's movements upon its climate. Milanković mathematically theorized that variations in eccentricity, axial tilt, and precession of the Earth's orbit determined the climatic patterns on Earth, resulting in 100,000-year ice age cycles of the Quaternary glaciation over the last few million years [24, 31]. The Earth's axis completes one full cycle of precession approximately every 26,000 years. At the same time, the elliptical orbit rotates, more slowly, leading to a 23,000-year cycle between the seasons and the orbit. In addition, the angle between the Earth's rotational axis and the normal to the plane of its orbit moves from 22.1 degrees to 24.5 degrees and back again on a 41,000-year cycle. Currently, this angle is 23.44 degrees and is decreasing. The Milanković theory of climate change is not perfectly worked out; in particular, the largest observed response is at the 100,000-year timescale, but the forcing is apparently small at this scale, in regard to the ice ages [16]. Various types of feedback (from $\mathrm{CO}_{2}$, or from ice sheet dynamics) are invoked to explain this discrepancy $[23,29,30]$. Some researchers have found a connection between monsoons and Milanković cycles [10].

Ignoring anthropogenic and other possible sources of variation acting at frequencies higher than one cycle per 19,000 years, the Milanković model predicts that the long-term

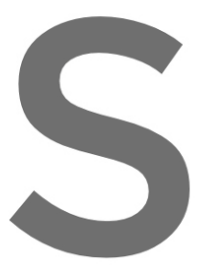
cooling trend whi Now the Earth is (insolation) in the Northern Hemisphere at ice age. Astronomical calculations show tha gradually over the next 25,000 years, and th sufficient to cause an ice age are expected
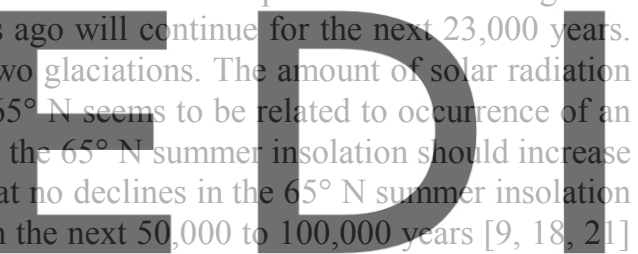

(Figure 6).

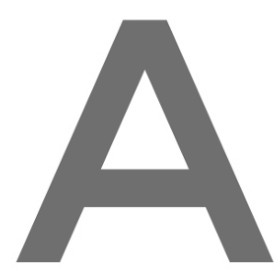

Register for free at https//www.scipedia.com to download the version without the watermark

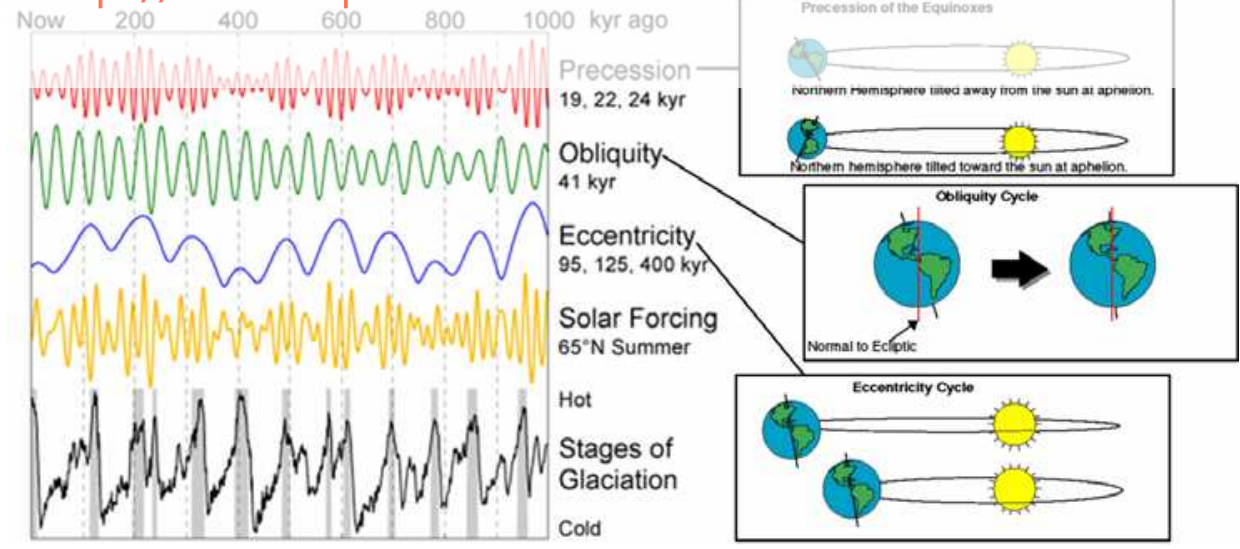

Fig. 6. The Milanković cycles and climate changes 
Thus the Southern Hemisphere seasons should tend to be somewhat more extreme than the Northern Hemisphere seasons. The relatively low eccentricity of the present orbit results in a $6.8 \%$ difference in the amount of solar radiation during summer in the two hemispheres.

The Milanković hypothesis was proved and became a theory by the correlations of its astronomical parameters and the oxygen isotope samples from deep ice core (500-952 m) from Antartica [16]. Hays et al. [16] measured the oxygen isotopic composition of planktonic foraminifera which are sensitive to climate changes. In the nineteen-twenties the theory was also applied to the temperatures of the Moon, Mars and Venus (very successful in the first two cases, but failed in the third).

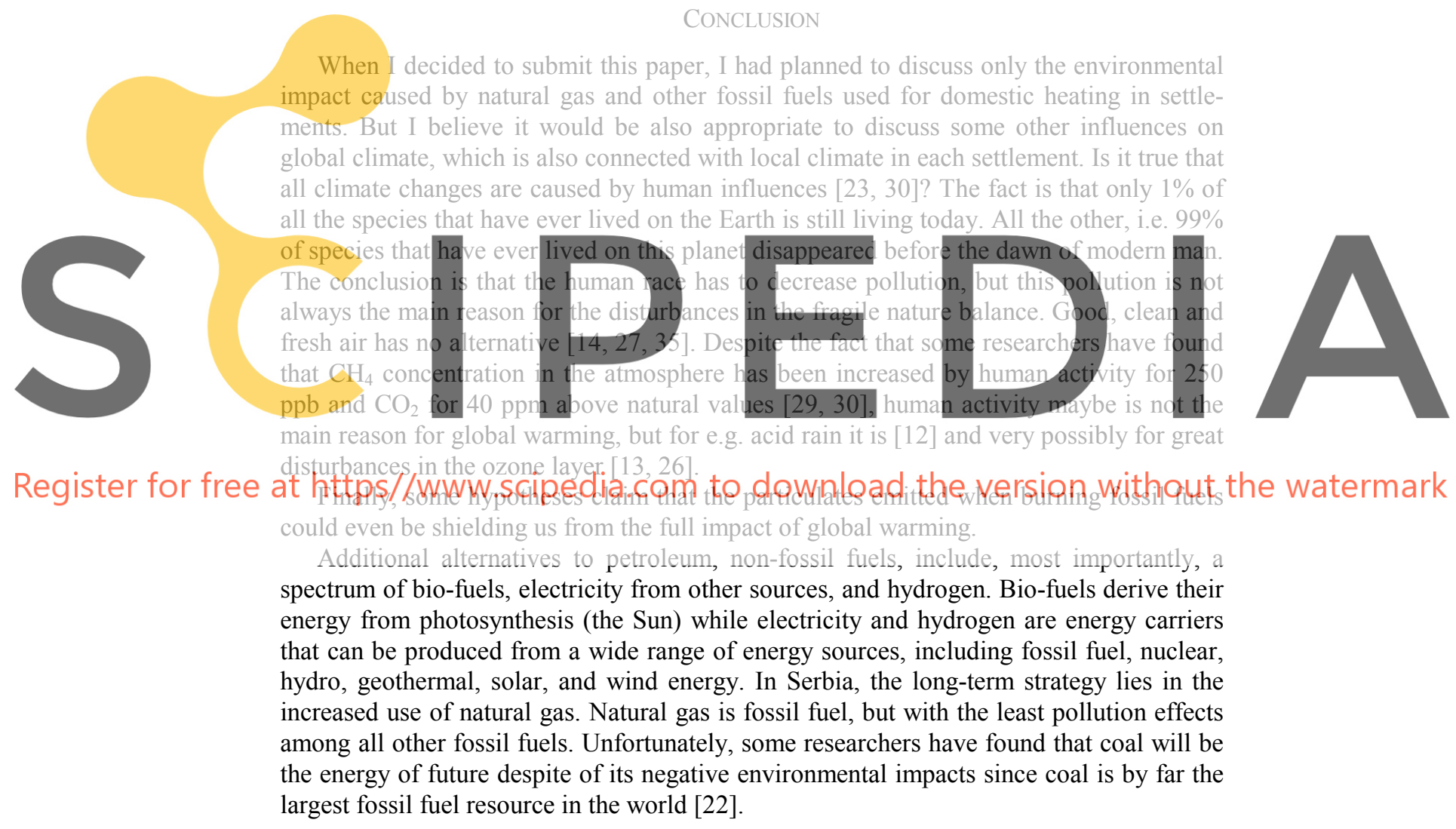

\section{REFERENCES}

1. Aikawa M., Hiraki T., Eiho J., Miyazaki H.: Air temperature variation with time and thermally evaluated atmospheric conditions correlated with land use change in urban areas of Japan. International Journal of Climatology, Vol. 28, No. 6, pp. 789-795, 2008.

2. Anonymous: US satellite images show where natural gas goes up in smoke. Professional Engineering, Vol. 20, No. 16, p. 7, 2007. 
3. Avakumović J.: Energetika kao izvor zagađivanja životne sredine. Ecologica, Vol. 15, No. 51, pp. 33-38, 2008. /in Serbian/

4. Barry P.J.: A statistical approach to the air pollution problem of chimney emission, Atmospheric Environment, Vol. 3, No. 3, pp. 328-330, 1967.

5. Brkić D., Tanasković T.: Systematic approach to natural gas usage for domestic heating in urban areas. Energy, Vol. 33, No. 12, pp. 1738-1753, 2008.

6. Brkić D.: Natural gas heating in Serbian settlements according to urbanity parameters. Facta Universitatis: Architecture and Civil Engineering, Vol. 6, No. 1, pp. 139-153, 2008.

7. Brkić D.: Transportation: Serbian, Russian pipeline accord enhances European gas security. Oil \& Gas Journal, Vol. 106, No. 48, pp. 52-54, 2008

8. Brkić D.: Serbian gas sector in the spotlight of oil and gas agreement with Russia. Energy Policy, Vol. 37, No. 5, pp. 1925-1938, 2009.

9. Broecker W.S.: The end of present interglacial: How and when? Quaternary Science Reviews, Vol. 17, No. 8, pn. 689-694, 1998

10. Clemens S., Wang P., Prell W.: Monsoons and global linkages on Milankovitch and sub-Milankovitch

time scales. Marine Geology, Vol. 201, No. 1-3, pp. 1-3, 2003

11. Csanady G.T.: On the problem of the 'Effective chimney heights', Atmospheric Environment, Vol. 2, No.3, pp. 232-243, 1967.

12. Đorđević M.: Kisele kiše i efekat staklene bašte kao posledica aerozagađenja. Ecologica, Vol. 14, No. 49, pp. 37-42, 2007. /in Serbian/

13. Đorđević M.: Ozonski omotač. Ecologica, Vol. 15, No. 51, pp. 29-32, 2008. /in Serbian/

14. Fenger J. Urban air quality. Atmospheric Environment, Vol. 33, No. 29, pp. 4877-4900, 1999.

15. Ghafghazi S., Sowlati T., Sokhansanj S., Melin S.: A multicriteria approach to evaluate district heating system options. Applied Energy Vol. 87, No. 4, pp. 1134-1140, 2010.
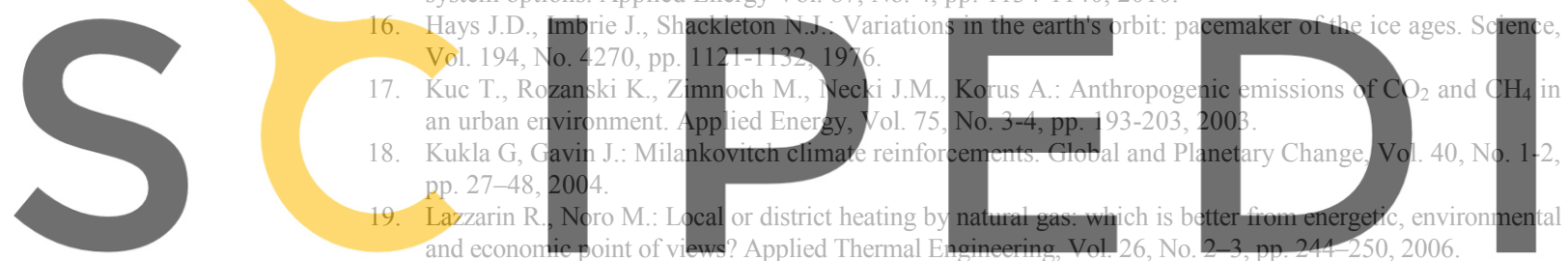

20. Levander $T$.: The relative contributions to the greenhouse effect from the use of different fuels. Atmospheric Environment, Vol. 24A, No. 11, pp. 2707-2714, 1990. Science Letters, Vol. 131, No. 1-2, pp. 17-26, 1995.

22. Longwell J.P., Rubi E.S., Wilson J.: Coal: energy for the future. Progress in Energy and Combustion Science, Vol. 21, No. 4, pp. 269-360, 1995.

23. Michard G.: External geophysics, climate and environment: Can we explain atmospheric carbon dioxide oscillations during the past 400,000 years? Comptes Rendus Geoscience, Vol. 340, No. 8, pp. 483-494, 2008.

24. Milanković M.: Kanon osunčanja i njegova primena na problem ledenih doba. Beograd, 1941. /in German, Serbian translation 1997, English translation 1969/

25. Nel W.P., Cooper C.J.: Implications of fossil fuel constraints on economic growth and global warming. Energy Policy, Vol. 37, No. 1, pp. 166-180, 2009.

26. Popović D., Đorđević A., Radosavljević J.: Chemical cycles of the stratosphere ozone disintegration. Facta Universitatis: Working and Living Environmental Protection, Vol. 1, No.5, pp. 51-59, 2000.

27. Raos M., Živković Lj.: Engineer's strategy for air pollution control. Facta Universitatis: Working and Living Environmental Protection, Vol. 4, No. 1, pp. 49-54, 2007.

28. Reddy B.S., Assenza G.B.: The great climate debate. Energy Policy, Vol. 37, No. 8, pp. 2997-3008, 2009

29. Ruddiman W.F.: Orbital insolation, ice volume, and greenhouse gases. Quaternary Science Reviews, Vol. 22, No. 15-17, pp. 1597-1629, 2003

30. Ruddiman W.F.: The challenge of modeling interglacial $\mathrm{CO}_{2}$ and $\mathrm{CH}_{4}$ trends. Quaternary Science Reviews, Vol. 27, No. 5-6, pp. 445-448, 2008.

31. Ribnikar S.V.: Na četrdesetogodišnjicu od smrti: Milutin Milanković i astronomska teorija klime. Hemijski pregled, Vol. 39, No. 1-2, pp. 15-21, 1998. in Serbian

32. Saïd N.M., Mhiri H., Le Palec G., Bournot P.: Experimental and numerical analysis of pollutant dispersion from a chimney. Atmospheric Environment, Vol. 39, No. 9, pp. 1727-1738, 2005. 
33. Sellwood B.W., Valdes P.J.: Jurassic climates. Proceedings of the Geologists' Association, Vol. 119, No. 1, pp. $5-17,2008$

34. Veenhuysen D, Hofschreuder P.: Methane emission of the Amsterdam urban area. Climate Change Research: Evaluation and Policy Implications, Vol. 107, No. 1-4, pp. 603-606, 1995.

35. Živković N., Đorđević A., Janković Ž., Nikić D.: Quality mark of air in city of Niš, based on measured concentration of $\mathrm{SO}_{2}$ and soot between 1980 and 2001. Facta Universitatis: Working and Living Environmental Protection, Vol. 2, No. 4, pp. 235-242, 2004.

\title{
DA LI SU FOSILNA GORIVA GLAVNI UZROK SADAŠNJEG GLOBALNOG ZAGREVANJA?
}

\author{
Dejan Brkić
}

Gas se uobičajeno uzima kao poželjno gorivo, naročito kada se uzme u obzir očuvanje životne sredine. Prirodni gas je šansa da Srbija ostvari održivi razvoj i da sa njegovom intenzivnom potrošnjom uskladi ideal tzv. 4E (Energija, Ekonomija, Efikasnost $i$ Životna sredina; eng. Environment). U ovom radu se upoređuju uticaji različitih fosilnih goriva koja se koriste za grejanje u domaćinstvima sa posebnim osvrtom na prirodni gas. Neki od ostalih uzročnika klimatskih promena se takođe razmatraju kao npr. Milankovićevi astronomski ciklusi. Uticaj ovih faktora na klimu će se uporediti sa klimatskim promenama uzrokovani upotrebom fosilnih goriva.


Register for free at https//www.scipedia.com to download the version without the watermark 